\section{Terrorist financing beyond 9/11}

\section{Loretta Napoleoni}

$\mathrm{J}$

hadist terrorist financing is the most challenging aspect of terrorism today. So far it has shown a remarkable ability to adapt to counter-terrorism legislation; it has mutated and by doing so it has been unaffected by ad hoc measures introduced to curb its growth.

The U.S.-led war in Iraq, in particular, triggered major metamorphoses in the structure and financing of the Jihadist movement in Europe and the Middle East, as shown by the investigation of the 7 July 2005 London bombings. Far from curbing the growth of Islamist terror, the Iraqi insurgency activated a new network of loosely connected, home grown, self-funded Jihadist cells. Their inspirational icon was a new, legendary terror leader, Abu Musab al Zarqawi. A skillful manipulator, he exploited the mythology manufactured by the United States around his figure, as well as the war in Iraq, to turn the battered al Qaeda - a small transnational armed organization - into a global anti-imperialist ideology, i.e., al Qaedism. ${ }^{1}$ European counter-terrorism intelligence concurs that al Zarqawi’s activity in Iraq became the driving force behind new, self-funded terror networks in Europe and the Middle East. Today, after his death, this network has a life of its own.

Jihadist terrorist financing is the most challenging aspect of terrorism today. It has adapted to counter-terrorism legislation and mutated so as to be unaffected by measures introduced to curb its growth.

Outside Europe, terrorist financing has also rapidly evolved. A U.S. secret interagency report on the Iraqi insurgency produced in June 2006, shows that not only is the Iraqi insurgency self-funded, but it has excess cash. ${ }^{2}$ If this is correct, it is likely that the Iraqi insurgency may use the spare cash to fund attacks abroad, e.g., in the West. It seems that Iraq is fast developing into a failed state similar to Afghanistan during the Taliban regime, a safe haven for Jihadist organizations and for their finances. (The 11 September 2001 attacks - 9/11 for short - were funded and masterminded while al Qaeda headquarters were in Afghanistan).

Since 9/11, all major evolutions in terrorist financing have taken place while governments have introduced counter-terrorism legislation, legislation which has systematically been bypassed by armed groups. To understand how and why these measures have failed one has to accept that terrorist financing is a dynamic phenomenon with a remarkable ability to circumvent new laws and to reinvent itself. The lesson to learn is that to win the financial battle against the Jihadists, governments must be able to predict the next move, to anticipate the next mutation.

This brief article analyzes the policies implemented to fight terrorist financing and shows how terrorist financing has been able to mutate despite them.

The financial war on terror

Prior to 9/11, the GDP of the New Economy of Terror - money generated by all armed organizations around the world - was $\$ 500$ billion. ${ }^{3}$ The currency used inside the terror economy was the U.S. dollar, and the most common denomination was the 100 dollar bill. This calculation includes wealth generated by armed organizations as well as the economy of state-shells, regions which are controlled by armed groups, and warlords, for example, in the eastern Congo. One third of the New Economy of Terror was generated by legitimate businesses, ranging from donations from businessmen to salaries of members of armed organizations; the other two thirds of the $\$ 500$ billion was money laundered in U.S. dollars inside the United States. The most important source of revenues for armed organizations was smuggling of narcotics. Al Qaeda's finances represented a very small fraction of the New Economy of Terror.

Following 9/11, the two main policies implemented to counter terrorism financing were the Patriot Act and the Terror Lists. Neither of these were part of a multilateral response to 9/11; instead they were the result of America's decision to take the lead in all aspects of the "war on terror," including countering terrorist financing. ${ }^{4}$

The Patriot Act is primarily an anti-money laundering legislation which did not address the problem of terror money generated by legitimate businesses. Because it was introduced only in the United States, the act did not reduce the flows of criminal and terror money but rather caused the shifting of the epicenter of money laundering activity from the United States to Europe. To date Europe does not have homogeneous legislation to combat money laundering or to regulate offshore facilities. Italian magistrates investigating the Milan mosque in Via Quaranta discovered that the cell received funds, denominated in euros, from Arab countries via British offshore accounts. ${ }^{5}$ It is important to stress that with the introduction of the euro, once money has successfully entered the European banking system, it can be wired and withdrawn anywhere without any controls. Members of terror groups operating in Europe use ATM machines, as the $9 / 11$ hijackers did, to access the cash made available by their sponsors. Those who participated in the Bali, Istanbul, and Madrid attacks also used ATM machines. ${ }^{6}$

Against this background, Europe has become the most important international hub for the criminal, illegal, and terror economy and the euro the currency used to conduct most money laundering activities. The United Kingdom, in particular, with its offshore facilities and attractive fiscal legislation, is an ideal money laundering hub. Thus the Patriot Act ended up damaging Europe while protecting America.

The Terror Lists, registers of people and companies suspected of bankrolling terror organizations, were also not implemented globally. Several countries did not participate in this initiative because of the unconstitutionality of blacklisting people 
only on suspicion, others were forced to back off after being taken to court by people whose names appeared in the lists, and some countries simply did not comply with the lists. To date a comprehensive list of lists does not exist.

The failure of the two major financial anti-terrorist pieces of legislation becomes apparent when considering that since 9/11 - and despite the destruction of the Taliban regime, the disappearance of al Qaeda as a transnational armed organization, and the invasion of Afghanistan and Iraq - the size of the New Economy of Terror has not shrunk. In total, no more than $\$ 200$ million in terror money has been frozen across the world. And this is a very optimistic estimate; a more realistic one is \$125 million.

More likely, the New Economy of Terror has grown, ${ }^{7}$ as we now have to add to it:

$<$ The proliferation of state-shells run by warlords, militias, and Jihadist groups in countries such as Iraq, where, prior to the invasion, armed organizations did not operate.

$<$ The creation of new joint ventures between crime and terror, e.g., in Latin America, where partnerships among narco-traffickers, armed groups, and members of populist governments have been established.

$<$ The rise in oil prices which has generated a surge of wealth in Arab oil-producing countries which have traditionally sponsored Islamist groups; until recently, part of this wealth bankrolled the insurgency in Iraq via a fleet of cash couriers.

$<$ The development of new drug routes, for example cocaine from Colombia to Europe, where drug money is laundered and invested in property.

$<$ The birth of a network of Jihadists in Europe who self-fund their terror activity.

\section{Restructuring Islamist terrorist finances}

The most remarkable change since 9/11 has been the restructuring of Jihadist finances. At the end of April 2006, the three videos issued by bin Laden, al Zarqawi, and al Zawahiri confirmed the success of such restructuring. In the messages, al Qaeda's leaders did not mention money or talk about their financial needs. This is a clear indication to their sponsors that there is no shortage of cash. The U.S. secret report completed in the summer of 2006 on the Iraqi insurgency also stresses that a major restructuring has taken place in Iraq, even to the extent that the insurgency is today financially self-sufficient. One could argue that several local groups have successfully privatized terrorism financing, i.e., they have sought ways to self-fund themselves while still operating under the ideological umbrella of “al Qaedism.” This privatization took place during the globalization of terrorism in the 1990s. Groups such as the 7 July 2005 London bombers, as well as the Iraqi insurgency, have conducted this privatization.

The main characteristics of this privatization within the globalized trade mark of al Qaeda are: the decentralization of the funding activity in Europe and in the Middle East, the strengthening of self-funding activity via legitimate businesses, and the financial independence of the Iraqi insurgency. These changes have taken place while the cost of carrying out terror attacks has been plummeting (as will be seen later on).

The new model of terrorism financing

Following the fall of the Taliban regime, the disintegration of al Qaeda triggered the disappearance of its global financial structure, the one used to mastermind the U.S. embassy bombings in Africa, the attack against the USS Cole in Yemen, and the destruction of the World Trade Center in New York.

Until 9/11, al Qaeda was a small transnational organization, hardly known outside its small group of sympathizers. It was funded by a complex network of investments and sponsors, whose primary aim was to bankroll training camps in Afghanistan where Muslim warriors were forged for eventual deployment wherever needed, e.g., Kashmir, Chechnya, Kosovo, as well as New York. 9/11 was the last transnational attack funded by al Qaeda; all others since then were self-funded by groups ideologically linked to al Qaeda. (In the first Bali bombing, where al Qaeda did participate as a financial partner, the money had been transferred before 9/11.)

The reshaping of al Qaeda's global financial structure along decentralized lines was triggered by the invasion of Iraq. The war offered a dissolved al Qaeda the opportunity to transform itself into al Qaedism, the global anti-western ideological umbrella under which the radicalization of European and Middle Eastern groups took place. Images of the Iraq invasion fiasco traveled across the world, fueling a deeplyrooted sentiment of solidarity and humiliation among Muslims. The presence of European troops in Iraq gave birth to an anti-European sentiment among radical Muslims, many of them born in Europe. This is a novel sentiment. Up until 9/11 Osama bin Laden had clearly stated that al Qaeda's fight was against the United States, perceived as the far away enemy which backed the near enemy, the corrupted oligarchic Muslim rulers.

Until 9/11, the main task of the European terror network was to supply funds and recruits for Islamist armed groups abroad, i.e., outside Europe. French-born Zacarias Moussaoui, the alleged 9/11 twentieth hijacker, for example, reached London penniless and in search of his own identity as a Muslim. The European mosque network provided him with financial and emotional support. Once ready, he was sent to Afghanistan where al Qaeda put him through extensive training and eventually selected him to travel to America. Thus Europe was a base to raise money and to recruit people; it was never a target. This situation changed dramatically after $9 / 11$, in response to the financial war on terror. 
Money, which in the past had gone to fund distant Jihadist fights in Bosnia, Kashmir, Sudan, and including al Qaeda in Afghanistan, was diverted to sustain a new breed of Jihadists in Europe and the Middle East. Thus the Casablanca and Madrid bombers had no direct links with Osama bin Laden but used funds gathered in Europe by al Qaeda's network. Suddenly, people did not need to raise money to travel to the camps in Afghanistan and Pakistan; they could fight in the streets of their towns. The presence of coalition forces in Iraq allowed Osama bin Laden, Abu Musab al Zarqawi, and Ayman al Zawahiri to become icons of al Qaedism, semi-supernatural figures, people who inspire the Jihadists.

The decentralization of al Qaeda's funding activity is the direct consequence of the transition of Europe from an operational base and a fund-raising continent into a primary target. The Middle East experienced a similar transition. While in the past al Qaeda's enemy was the United States, European Jihadist groups have focused their fight inside the continent and linked it to the war in Iraq. In a chilling video recorded before the 7 July 2005 London attack, one of the perpetrators justifies his decision to become a suicide bomber by reference to avenging U.S. forces' killings of Iraqis. European cities are today primary targets, as proved by the Madrid and London attacks and clearly stated by the Islamist leadership in subsequent statements. "Strikes within cities are a type of military diplomacy,” stated Al Battar, al Qaeda’s virtual magazine issued after the attack in Madrid. "This type of attack is often written with blood, embellished with body parts and perfumed with gunpowder."8 The document is a chilling reminder of the reasons why, since the tragic events of $9 / 11$, the incidence of terror attacks in Muslim and Western cities has continued. "Strikes bear a political meaning related to the conflict in ideology. They are considered a message sent to multiple parties, thus choosing the targets is done with extreme precision." ${ }^{9}$ Most European intelligence services are adamant that several attacks are currently in the pipeline. After the Madrid March 2004 attack, even European politicians admitted that the danger was very serious, and the London attacks in July 2005 demonstrated that existing counter-terrorism measures were not sufficient to prevent repeated attacks on mass-transit targets.

Home-grown groups rely on several proven techniques to raise funds for themselves, using both legitimate and illegitimate activities. Funds gathered by the mosque network belong to legitimate activities; this is clean money, legally earned, which is then diverted to fund terror groups. Members of Islamist armed organizations often have legitimate jobs. In Spain and in Italy, several of them worked as mechanics and waiters to support themselves and reduce the financial burden on the organization.

Legitimate funding is sufficient to bankroll Jihadist terrorist activity because the attacks are small-scale replicas of 9/11, which is the template. Any financial constraint is bypassed by adapting suicide missions according to the available budget. Homegrown groups, some of which we should call "improvised terrorists," for example some of the London bombers who were recruited and indoctrinated in less than a year, do not have well developed connections with the world of crime. Yet they find it easy to raise money through a network of friends, even family, and using their own savings. Thus self-funding via legitimate businesses becomes their main financial source.

Self-funding and decentralization have been successful because the unit cost of terror attacks has declined sharply since 9/11. The execution of the U.S. attacks cost half a million dollars, the Madrid bombing 10,000 dollars, and the London suicide missions less than 3,000 dollars. The killing of Theo Van Gogh in Holland probably cost less than $\$ 100$ but the impact has been enormous, turning many Dutch people from tolerant to intolerant toward ethic and religious groups.

\section{Conclusions}

It is now apparent that it was 9/11 that prompted a major metamorphosis inside the Jihadist movement. The desire of radical Islamist groups to emulate 9/11 coupled with counter-terror measures such as the war in Iraq, fueled the network's transformation. This is especially true since counter-terror measures have been and are still perceived by Muslims, including European-born, as hegemonic and anti-Muslim. Moreover, since 9/11 Europe has seen the spontaneous emergence of home-grown Jihadist groups whose members have not been trained in Islamist camps in Afghanistan or Sudan, as was the case of the cells that carried out the Madrid and London attacks. ${ }^{10}$ These groups have no official links with al Qaeda or Osama bin Laden but operate under the ideological umbrella of a new creed: al Qaedism.

Terrorist financing is still evolving. Home-grown, self-funded Jihadist groups are today operating in Europe under the umbrella of a new anti-imperialist ideology: al Qaedism. After 9/11, these groups have used terror financiers' seed-money which landed in Europe after the introduction of the Patriot Act to start their activity. Recognizing al Zarqawi as their new icon, they are motivated by the war in Iraq. Unlike al Qaeda, their primary target is not the United States but Europe. Today, these groups need very little money to carry out attacks inside European cities, so little indeed that they can easily self-fund their activity. Against this new scenario, Osama bin Laden does not need to plan, plot, and fund another 9/11. All he needs to do is to issue a call to implement a thousand, small-scale replicas of such an attack. It is this new reality and its future development that European countering-terrorism financing should address.

Notes

Loretta Napoleoni is writes on terrorism financing and advises several governments on counter-terrorism. She is senior partner of G Risk, a London-based risk agency. She can be reached at http://lorettanapoleoni.com/contact/.

1. Napoleoni (2005). 


\section{Burns and Semple (2006).}

3. The points and claims made in this paragraph are elaborated upon in Napoleoni (2004).

4. Report of the Countering Terrorist Financing group for the Club of Madrid, Conference on Democracy and Terrorism, Madrid, March 2005. http://summit.clubmadrid.org/index.html [accessed 10 December 2006].

5. "Tentacles of Terror: Ansar al-Islam Goes International, Causing Tremors.” The Daily Star [Beirut]. 29 March 2004.

6. Ibid.

7. I have estimated that from 9/11 to the end of 2005 the New Economy of Terror has grown between 4 to 6 percent. See Napoleoni (2005).

8. “Al Battar Training Camp, Northeast Intelligent Network.” March 2004. www.homelandsecurityus.com.

9. Ibid.

10. Graff (2004)

\section{References}

Burns, J.F. and K. Semple. 2006. "U.S. Finds Iraq Insurgency Has Funds To Sustain Itself.” The New York Times. 26 November 2006.

Graff, J. 2004. “Terror's Tracks.” TIME Europe. 11 April 2004. http://www.time.com/time/europe/magazine/article/0,13005,901040419-61002 3,00.html [accessed 10 December 2006].

Napoleoni, L. 2004. Terror Incorporated. New York: Seven Stories Press.

Napoleoni, L. 2005. Insurgent Iraq, al Zarqawi and the New Generation. New York: Seven Stories Press. 